\title{
The Scientific Perspective on Moral Objectivity
}

\author{
Catherine Wilson ${ }^{1}$
}

Accepted: 3 March 2017 / Published online: 21 March 2017

(C) The Author(s) 2017. This article is published with open access at Springerlink.com

\begin{abstract}
The naturalistic approach to metaethics is sometimes identified with a supervenience theory relating moral properties to underlying descriptive properties, thereby securing the possibility of objective knowledge in morality as in chemistry. I reject this approach along with the purely anthropological approach which leads to an objectionable form of relativism. There is no single method for arriving at moral objectivity any more than there is a single method that has taken us from alchemy to modern chemistry. Rather, there is an ensemble of (cognitive) instruments, techniques, experiments and observations that contribute to eliminating moral error, delivering what we are entitled to call greater objectivity.
\end{abstract}

Keywords Moral naturalism $\cdot$ Moral objectivity $\cdot$ Relativism $\cdot$ Moral progress $\cdot$ Moral epistemology $\cdot$ Evolutionary ethics $\cdot$ Is-ought problem $\cdot$ Altruism

'Moral naturalism' is sometimes characterised as the view that there are objective moral facts and properties which are at the same time elements of the natural world (Copp 2007: 2-3). On some popular versions of this view (Smith 2004; Jackson and Pettit 1996), moral properties supervene on nonevaluative properties. For example, the properties of 'cruelty' 'wrongness' and 'not to be done-ness' might be said to supervene on the action of whipping a whimpering dog. In all possible worlds, the claim is, the moral properties of an action, event, person or situation will be present whenever the action, event, situation or person has the descriptive properties that it does, just as wherever there is $\mathrm{H}_{2} \mathrm{O}$ there will be water. By this means the objectivity of moral judgements is allegedly secured; it is not a matter of our preference or decision that some liquid is water or not; this depends entirely on whether it is $\mathrm{H}_{2} \mathrm{O}$ or not, and the latter is assuredly not a matter of our preferences or decisions.

Such accounts have long-recognised defects. The supervenience concept is strained for there is general agreement on what liquids are water; but scientific investigation revealed its hidden substructure long after people had confidently talked about that liquid. With 'cruelty' it's the other way around: there will be general agreement over what is 'descriptively'

Catherine Wilson

cww899@gmail.com

1 University of York, York, UK 
happening when a beaten dog is whimpering; its evaluative properties are open to theoretical discussion. Intellectual enquiry in moral theory might appear to be dedicated to trying to figure out the underlying descriptive properties of, for example, a 'just war' or a 'humane diet,' but this process is really aimed at discovering the extension of these terms, whereas the investigation of water's chemical properties is not aimed at discovering the actual extension of the term 'water.'

Other moral naturalists maintain that moral properties are 'secondary qualities' like colour (McDowell 1988); they are 'detected' and may be said to supervene on certain configurations of surface reflectances, light, eyes and brains. Although they are 'response-dependent,' secondary qualities are on this view not subjective, for some colour judgements are just erroneous. That this tomato is red can be objectively true, said of sometomato, and moral error is seen under this scheme as analogous to colour blindness or perception under disturbed conditions. But how did we develop the test for normal moral perception?

These versions of moral naturalism are inherently metaphysical, and in view of the difficulties with the available analogies, they are best regarded as capturing something of the phenomenology of moral experience; it feels as though we directly perceive the cruelty in the treatment of the whimpering dog and it seems as though by intellectual effort we could discover the underlying features of just wars and humane diets.

Another way to think of moral naturalism is as a repudiation of metaphysics which makes no pretence at saving moral objectivity. From the non-metaphysical, that is to say, biological, anthropological and sociological perspectives, moralities are simply local practices of interaction between persons relating to the harms and benefits they can do one another that are endorsed or repudiated by individuals and communities. The practices correspond to beliefs and the judgements that express them and are linked to perceptual and emotional experiences (Harman 1977; Prinz 2007). Moral codes are particularly concerned with prohibitions on sex and aggression, and with duties and privileges with regard to to kin, superiors, and inferiors. Although there is universal human agreement that these matters are candidates for regulation and sanctioning for infringement of the rules, there is disagreement as to what the rules ought to be, over whether individuals have infringed the rules, and there are changes over time of attitudes and practices.

Moral prohibitions and permissions have analogues in the behaviour of other social animals that have evolved by natural selection. Sharon Street poses a 'Darwinian dilemma' in this connection (Street 2006). She departs from the premise that either we possess moral intuitions that we cannot trust, insofar as we recognise that they are produced in brains manufactured by selfish genes whose interest is in getting themselves into the next generation; or else natural selection has somehow 'favoured ancestors who were able to grasp' what she terms 'independent' moral truths. So we may be led to fictionalist analyses (Joyce 2002), according to which the underlying anthropology, biology, and sociology of moral discourse and practice is truth-apt, but moral discourse itself implicates a fictional world of fictitious facts and fictitious qualities. Our emotions and reactions are real on this view; our instructional and coercive practices are actual and concrete, but what we argue and legislate about is completely unreal. According to E.O. Wilson and Michael Ruse, morality is an illusion that our genes use 'to get us to behave' (1985). And for Ruse (2006), 'an important part of the moral experience is that we objectify our substantive ethics.'

From the anti-metaphysical naturalistic perspective, it seems that moral beliefs and practices can be described and evaluated, but that evaluation can only be relative to a chosen local 
framework. This position is articulated by Jesse Prinz, who offers a subject-relativised analysis of the notion of moral truth, and by Street who offers an analogously subject-relativised characterisation of the right thing for an individual to do in the circumstances with which they are presented. I will first explain these views as I understand them, but then suggest how to think of moral objectivity in the absence of truth-conditions for moral claims. For, as I believe these two philosophers effectively show us, we can have either truth conditions or objectivity as it is understood by the metaphysical wing of moral naturalism, but not both.

\section{I}

According to Prinz, 'To believe that something is morally wrong (right) is to have a sentiment of disapprobation (approbation) towards it. '(2006, 33). His updated version of moral sentimentalism in The Emotional Construction of Morals (2007) is scientifically impressive: It is anthropologically wide-ranging, based on familiarity with actual practices and beliefs of numerous human groups, past and present. It is also neurologically informed, based on plausible accounts of the cerebral mechanisms involved in moral judgements. In his semantics for moral propositions, moral judgments nominally reflect beliefs but in fact express sentiments.

As he explains it, a moral judgement is indexical. (2007, 199).' Like the statement 'I am hungry,' it cannot be assigned a truth value until we have identified the referent of 'I.' The first statement, or the belief it expresses, is true in case the person uttering it or thinking it is in fact hungry and false otherwise. The moral judgement 'Desecration of dead bodies is wrong' when said (thought) by A is true on Prinz's account iff desecration of dead bodies is the type of action that tends to produce in A the sentiment of moral revulsion. Can A's thought or statement be erroneous? Yes: If I say, for example, 'George is dishonest' when in fact George has not done anything of a type to arouse in me a sentiment of disapprobation, I have said something false. But if the Aztecs had a policy of killing and eating captives, those Aztecs who believed of eligible captives that they ought to be killed and eaten did not believe anything false (2007, 195-6). Note that Prinz's semantics, like Blackburn's earlier version of expressivism (1984) does not imply that killing and eating captives is morally permissible. Were $I$ to say so, I would say something false, for the thought of the action in fact arouses sentiments of disapprobation in me and I identify with a group that has a policy against killing and eating captives.

Street's analysis of moral judgements in her essay on normative reasons (2008) is similarly based on the notion that we cannot get outside an individual's or group's framework of beliefs. She defends an antirealist but 'coherentist' account of truth, arguing that normative judgements are true for A if they are consistent with the whole set of judgements A would make, or attitudes A would hold if forced to reflect on the consistency of their values, hopes and plans, where A is some individual or some group. Summarising, on both accounts, statements about what ought to or may or may not be done must be considered as asserted or thought by individuals or representatives of groups or as evaluable only with individuated value-sets. However, neither account implies that what's 'true for them' has to be endorsed by me as 'acceptable practice for them,' even if not for me. 'All practices are permissible' is a general formula that can have no assertor-independent truth value; its truth value depends on the emotional dispositions or value set of whoever is thinking that. 
This is, however, a somewhat puzzling result. Consider an Aztec who has anticipated Prinz's analysis and who is aware that moral beliefs differ all over the world. The Aztec says. 'It's not morally permissible for most people to kill and eat their neighbours, but it is permissible for me.' Or the Sierra Leone mother who says 'It's obligatory for me to have my daughters circumcised, but it's not even permissible for most mothers around the world.' These judgements do not seem to reflect what we mean by 'morally permissible' or 'obligatory.' Street's claim, in turn, that what an agent ought to do needs assessment from within her value system has a distinguished precedent in Bernard Williams's insistence on the exclusivity of 'internal reasons' (Williams 1981). However, the analysis worked out in connection with self-regarding practical reasoning looks problematic when applied to moral reasoning. 'Alex's' decision whether or not to smoke clearly ought to depend on nothing more than his values and priorities and on statistics he ought to know about, as Street persuasively argues. But Sally's decision whether or not to take money and stamps from the secretary's desk when the latter is out for coffee, ought to depend on more than the features of Sally's value set. Both Prinz and Street will respond that in 'our' system it is perhaps not permissible for her to do so, on account of our values, but then what is added to the supposition that Sally decides to steal the stamps and money and believes this to be permissible, by making her judgement true or justified in her framework?

There are no formal inconsistencies in these accounts, and they both present an important idea: namely, that we must construct and so improve our belief systems 'from the inside.' But even while we avoid spurious metaphysics and gain integration with anthropology and psychology, we seem to have lost something that made moral knowledge seekable and worth seeking and its absence shameful or blameworthy. The question is, how can we use the insights provided by evolutionary and anthropological accounts of the origins and diversity of moral beliefs, emotions, perceptions, and practices, whilst defending the notion that some moral judgements are better than others in as objective a sense as possible?

Why does objectivity matter? In the natural sciences, confidence in the objectivity of a theorem or equation or causal statement gives us the assurance that it is safe to interfere with reality on its basis: to build the bridge, or prescribe the drug. In moral theory, objectivity matters because knowledge that we are doing the right thing -if we can get it-can give us confidence that we are avoiding moral harm to others, even in circumstances in which our actions produce pain or resentment, and confidence that criticism, interference, and on occasion resistance to other people's wishes and disregard for their preferences are justified. Objectivity justifies us in expressing resentment, outrage, moral alarm, and sometimes in retaliating or intervening rather than being tolerant and adopting a policy of to each his own.

Prinz recognises that we need some account of 'betterness' relations in moral belief sets. In two later chapters he discusses human practices and institutions that tend to arouse disgust or disapprobation and that come in for moral criticism by us 21 st C.westerners: namely cannibalism, incest, and polygyny. He suggests that learning about the history and anthropology of these institutions may change our sentiments towards them towards a less condemnatory stance. Although, in his words, 'Moral progress cannot be interpreted as a transition from one set of values to a morally better set of values,' we can make make 'progress that is not illusory,' by seeking 'moral values that are better in an extramoral sense' (2007, 297). One set of beliefs and practices is better than a competitor if it is not only more consistent, he thinks, but performs better on other criteria, such as reduced social tension, welfare and well-being, generality and universality, and consistency with biological norms $(2007,292)$. Thus internal 
coherence, logical consistency, and the satisfaction of external criteria are regarded by Street and Prinz as tests for the relative goodness or acceptability of moral claims.

\section{Ii}

Huw Price (2011) has recently argued that naturalism need not look for an account of how the statements of problematic discourses, including moral discourse, can fit the facts in the way the statements of the natural sciences have been supposed to do so. Instead, he suggests, following Rorty and other pragmatists, we should give up the notion that the statements of natural science mirror mind-and culture-independent reality and are therefore paradigmatically truthapt. Instead, we should look to how all our discourses function, how they are connected to our practices, and how they are put to use, especially in argumentation.

If we take this insight seriously, we can be liberated not only from both an unhappy relativism, and from awkward metaphysical theories of moral objectivity such as supervenience theory, but also from futile searches for criteria for moral truth. Rather than trying to state truth conditions for moral claims, including conditions articulated from an internalist perspective, we can make an entirely different kind of appeal to the sciences of nature, including the sciences of human nature, studying actual episodes of indisputable moral progress and understanding how they came about. Nonevaluative biological, ethnographic and psychological data, along with other sources of information, have a role to play here. Contrary to the cliché that you can't derive ought from is, our 'oughts' invariably rest upon ises, without being logically deducible from them. I will say more about this later in the paper.

Meanwhile, in adopting the naturalistic stance in moral theory, we can consider three distinct areas of research into the nonevaluative grounding of the evaluative. The first is the Darwinian level in which the evolutionary origins of morality in nonhuman animals are studied and modelled with a special focus on our closest non-human relatives amongst the primates. Darwin's own observations and speculations in The Descent of Man (1871) were pioneering in this respect. The second is the anthropological level in which the specific crosscultural features of human cognitive and emotional architecture that are relevant to morality are studied. The third is the cultural level in which we can examine belief change in ethics, the practices that discourage it or encourage it, and come to understand why, in particular cases, one belief or practice came to be accepted as better than its predecessor. In the same way that basic animal learning about the environment is succeeded and corrected by specifically human forms of learning involving imitation, teaching, symbolic representation and communication, and these universal forms were succeeded in turn by specialised methods such as looking underneath the appearances with special instruments, or employing statistical methods, the variety of original forms of moral discourse and practice in humans and other animals are extended and corrected by forms of human learning and these in turn are refined in technologically complex societies with developed forms of communication. At each level there are continuities and corrections.

The importance of the study of the evolutionary origins of morality for understanding moral objectivity is that it reveals to us the ubiquity and simultaneity of competition, conflict, and cooperation, also exploitation and protection. We have learned a great about the ways in which social animals monitor one another's behaviour, are aware of individual personalities and temperaments, and practice deception, avoidance, and assistance, in highly context dependent ways. The distinction between genes and their vehicles (Dawkins 1976) the organisms whose 
behaviour and morphology enables them to get into the next generation, explains why organisms formed by natural selection are never fully selfish in the vernacular sense, and instead can exhibit generosity, awareness of others' needs and feelings and responsiveness to them to the point of self-sacrifice.

Customarily the evolutionary origins of altruism are explained by biologists in game theoretic terms, imagining individuals playing different strategies of selfishness, altruism and reciprocity. These simulations revealed that a selfish strategy quickly dominates if introduced as a mutation into a population of altruists; that an altruistic mutation cannot dominate if introduced into a population of selfish individuals, but that a cautious strategy of 'grudging' titfor-tat, behaving altruistically towards all individuals at first encounter, but then selfishly unless reciprocated could succeed (Dawkins 1976, 166-8). As Kitcher points out, however, for these models to be relevant to the human case there would have to have been some point in our evolutionary history 'at which primates, great apes or early humans were forced into pairwise interactions of form of an infinitely repeated prisoner's dilemma' (Kitcher 2006, 160). Nor are such models helpful in understanding the evolution of symbiotic relationships such as that described by Trivers (1971) between the wrasse and the cleaner fish. So the question how can animals evolve to perform complex, costly actions cannot be answered in this way. But one might as well be puzzled as to how we evolved eyes. For the animals that have them, eyes are essential to survival and reproduction. But it is costly to build a visual system; the right genes have to produce the right optical and cortical architecture. So we look for small steps along the way, beginning with the evolution of cells that respond to light and with mechanisms for moving in response to the information and for gradual improvements to systems that can exploit the information in the electromagnetic properties of things to a greater and great degree. Ancestral cleaner fish that dared to come ever closer, ever more frequently to an ancestral wrasse's mouth must occasionally have met infested ancestral wrasse that were more tolerant than others. Selection on each type produced ever braver and ever more tolerant fish.

Tooby and Cosmides (1996) argue that animals' reinforcing and extinguishing reactions to low-cost, unintentionally provided benefits and harms are the small steps that will enhance or diminish the probability that they are performed in animals that experience social learning. Suppose, for example, I toss my half-eaten apple over my shoulder and you, starving, pick it up. You respond with gratitude and groom me. I become more likely deliberately to toss food your way and my gratitude behaviour is reinforced. Accidental harms when retaliated against can also develop considerate habits. Suppose I toss my half-eaten apple over my shoulder and it hits you in the eye, impairing your fitness. You deliver a punishment in the form of a lunge at me, impairing mine. Eventually deliberately harmful behaviour as well as thoughtlessly inconsiderate behaviour is moderated. My carelessness is deterred and I am spared future punishment and you keep your other eye. The 'Baldwin effect,' according to which traits that are first produced only under conditions of specific environmental triggers or stresses later show up across a range of conditions, is helpful in understanding these evolutionary processes (Ananth 2005).

Moving to the second level, we can ask what innovations in human emotional and cognitive architecture make the distinctive features of human morality as opposed to that of other social animals, especially the primates, possible. Here we should focus on such features as language, long childhood, post-reproductive longevity, the explicit awareness of complex kinship relations, and food sharing. Apes may eat communally and respond to begging, but the practice of hunter-gatherers of collecting food, bringing it home, and distributing it to the less or nonproductive adult members of the group as well is exclusively human. Conceptions of 
fairness, entitlement, and compassion have to be present to regulate this process. Further, humans engage in co-operative labour and intellectual effort in the manufacture of boats, food preparation, preparation for festivals, the planning of hunts and battles. Laziness is discouraged and punished, talent and insight are valued and rewarded. Conceptions of obligation to others, and pulling one's weight are needed to underpin this, as well as a reduction in irritability and a willingness to reconcile with former enemies (de Waal 1996, 2006). Finally, the human mating system diverges strongly from that of chimpanzees and bonobos, featuring as it does longlasting pairbonds, but with covert adultery, and complex emotions of jealousy, guilt, furtive attraction, and loyalty. Politically, although humans, like other animals, are inclined to defer to dominant individuals, there is a 'preference for equality' (Boehm et al. 1993) in huntergatherer groups under a critical size. Persons perceived as troublesome and aggressive may be assassinated or driven out of the group.

Tooby and Cosmides (1996) point to the development of individual personalities and competencies -the 'appetite for individuality' as highly significant in making people valuable to one another and ensuring their loyalty and help in times of need. A person has good reason to make themself irreplaceable by others by developing specialised skills and by cultivating 'deep engagement' with persons they in turn find irreplaceable. The importance of personality can explain many features of our altruism that reciprocal altruism and kin selection leave mysterious. Why do we feel duty bound to look after our aging parents when they are not going to produce more copies of our genes? Why do we feel duty bound to follow our leaders into war when we are going to get killed and produce no offspring at all? Why do we lavish our love and attention to men or women who will never give us any more children or even help us with the ones we already have? Our knowledge that we are irreplaceable to our parents, our long experience of their beneficence and uniqueness, create memories and expectations of benefits. People's tendency to remain in troubled relationships is evidence that, contrary to the old song, it's worse to be alone on the shelf than it is to be in love by yourself.

Because biology underdetermines behaviour even in nonhuman primates, which develop different local customs, we can expect diversity that sometimes reflects the environmental conditions faced by a geographically dispersed species that gets its food in different ways and the contingencies of its technology and relations with other groups. However, it also reflects gradual drift, spontaneous innovation, or sudden conversion into forms of cultural practice which differ as much as costumes and rituals. Peaceful and warlike tribes may differ little in their modes of subsistence or technologies or environmental constraints but profoundly in their cultural values and ideals. (Robarchek and Robarchek 1992). The result is the observed variety of systems especially concerning kinship obligations, sexual behaviour, and aggression against insiders and outsiders that characterise human groups. What they have in common are rules, whose effect is to render the social world more predictable and to reduce the need for stressful monitoring of other individuals (Gibbard 1990, 55-82; Kitcher 2006). Groups that adopt conventions, rituals, and moral rules cannot and do not need to encode them in the genes; they can be transmitted and maintained by social learning and sanctioning. They facilitate co-operative activities and reduce the costs of social interaction. Religious ideation was probably essential to this process of archaic code promulgation, as it implies retaliation by divinities or the cosmos even for unseen infractions. The alternation of fear of violating norms, including taboos, and ceremonies of worship and propitiation, with gratitude for one's continued existence and its enjoyments provides the emotional substructure for conformity. 
The third level on which morality can be studied as a phenomenon is as a set of beliefs, attitudes and practices that are subject to criticism and change in nonliterate as well as literate societies. Before going on to address moral change as a dynamic process, a brief characterisation of morally significant situations and actions is called for.

Moral problems and dilemmas also arise because we feel the pull of some possible sacrifice such as making sizable donations to charity but at the same time want to satisfy our own desires for entertainment, mental and physical exercise, and adornment. Moral argument sometimes recommends such sacrifices or the adoption of some burdens for the greater good. Sometimes, it denies that sacrifices are necessary or burdens are appropriate. Moral change occurs when new burdens are identified and deemed relevant to practices, or when the balance of burdens and benefits is recalculated. In technologically sophisticated societies, a wealth of new devices for gathering and interpreting information, for assessing burdens and benefits is available, and for comparing the effects of policies becomes available. The alternative ways of behaving or of organising one's society become clearer. Discussion and argument take information and the structures for analysing it from old beliefs and practices into new ones. In describing the Amazonian Waorani's abandonment of warfare after generations of vendettas that the tribespeople themselves could not see how to arrest, the Robarchek and Robarchek (1992) argue that the pattern changed when 'new cultural knowledge - new information and new perceptions of reality -allowed the formulation of new individual and cultural values and goals' (p. 207). One might point out that not all such conversions are morally progressive. But the reason a 'conversion' to fascism and genocide could not constitute moral progress is that the new values and goals acquired could not be founded in empirical reality; the readjustment of benefits and burdens could not be based on a more accurate assessment of people's actual and reasonable wants and needs.

\section{Iii}

The problem of moral objectivity is insoluble if it is approached by asking what properties have to be added to beliefs, or subjective values, or moral emotions or attitudes to qualify them as knowledge. Knowledge, it is sometimes said, is justified true belief not arrived at by wayward means: very well, but this formula does not help us to understand how an individual or a group or a society goes about acquiring knowledge, or losing or forgetting what they knew.

Imagine some alchemists meeting together in the fifteenth century. They have beliefs about the malign and beneficial influence of the stars, about the signatures of plants, and the efficacy of certain herbal tinctures when the herbs have been gathered by the light of the moon. They believe opium induces dreams and drowsiness and mercury cures syphilis. They begin to worry about whether their beliefs are actually true. Suppose they ask themselves, what would have to be added to our beliefs to make them true? Alas, there is nothing, from their perspective, that could be added. They can't anticipate the developments in instruments, techniques and theory that will lead to the rejection of some but not all of their beliefs. From our retrospective standpoint we can distinguish between the beliefs that are true and that aren't, and we can give an account of the history of chemistry that explains how rejection and acceptance came about. Sympathetic historiography can elucidate why the alchemists believed what they did and explain why many others have been subtracted from the corpus of knowledge.

Getting-to-know required the discovery or invention of entirely new methods of collecting information about stars and herbs and making a 'vexed' nature communicate her secrets. It 
also depended on ignoring certain time honoured beliefs and impressions of obviousness or plausibility. New methods of physical and quantitative analysis came into play. The invention of the printing press made the collation and organisation of data effective and efficient and stimulated processes of verification and criticism. We 'learned how to learn' about the properties of stars and herbs (See Mizrahi 2013).

In the same way, if Aristotle had asked himself what had to be added to his belief that slavery was in some cases just to make it the case that he knew that slavery was in some cases just, he could only have given the trivial answers that his belief would need to 'correspond to the facts' and 'be justified by appropriate arguments and considerations.' If we agree that the claim that slavery is wrong has the same degree of objectivity as the claim that the stars do not have a malign influence on human affairs, we can treat both discoveries as the end points of gradual processes of getting-to-know. We learned how to learn about morality, subtracting beliefs and altering conceptions as well as adding them. Unanticipated, unforeseeable methods of conceptual analysis, notably the utilitarian calculus and Kantian logic, combined with knowledge gathered from slave narratives and eyewitness descriptions of slavery. There is a narrative of knowledge acquisition - perhaps even several rival narratives-that can explain how we, the descendants of slaveholders, came to reject the practice. Analogous narratives can be supplied for the abandonment of routine torture, public hangings, burnings at the stake, the recognition of the rights of women, protective labour legislation, social security, animal welfare, and other instances of moral progress. As in the case of scientific progress, we may be able to envision what would constitute improvement in some domain concerned with sex, aggression, reciprocity, or duties to kin and others, but how or why the improvement came about is a story that can only be told after it does come about (Wilson 2010). Although Prinz is right to point to 'generality' as characterizing many notable instances of moral progress: we might think here of the extension of voting rights to the working classes andthe abandonment of clerical and aristocratic privileges, again, if there were any parameter on which an increase guaranteed an improvement in our views, we would not ever need to remain undecided on an issue, and we could scrutinize our existing beliefs to see if they were as general as possible.

If I declare a practice to be objectively wrong, I think there was or could be a narrative that would explain why we could get to this conclusion, and that there can be no reasonable narrative that will take us back from it. Logically, I know, there could be, just as logically it is imaginable that some series of experiments leads us back to phlogiston from oxygen. A retreat from the moral truth could also happen as a result of the loss of learning, the suppression of information, the banning of rational enquiry. But how theory and experience, rationally and responsively to observation, would lead us back to phlogiston is unimaginable. I can imagine that we return to slavery, torture, the claustration of women in the next century, but only as the result of the loss of information, and the control of knowledge and politics by a malevolent elite. In neither case does my conviction imply that I am trapped behind the veil of belief, anymore than the oxygen theorist is trapped in their commitment to standard chemistry. Truth is what we get to by employing discipline-specific procedures (Wilson 2011). And we should distinguish between positions that people may be passionately committed to such as vegetarianism or pacifism or abortion and positions that are truly terminal points of enquiry. On these topics, as on euthanasia, the jury is still out as far as our culture is concerned.

There are a number of objections to this view:

First, it might be argued that the theory is elitist. It puts the truth in the hands of the educated classes who have read their Plato, Bentham, Mill, and Kant and have some familiarity with the history of institutions. They are a minority of the human race; why should what they regard as 
instances of progress - moral truths discovered- be identified with the objectively true? Second, it might be argued that we accept correspondingly elite views in the natural sciences because they prove their status in practice by allowing for prediction and control, which moral truths do not do. Third, it might be argued that the objectivity of personal moral knowledge is not explained by the existence of historical narratives. Fourth, it will be argued that slavery was always wrong, and would always have been wrong, whether or not human processes of enquiry ever arrived at that result.

To the first objection, it can be replied that the discovery of noncommonsensical truths is always in the first instance in the hands of an elite; to the second objection, one might propose that moral progress relieves social tensions, diminishing the amount of ill-will in a society and the presentation of grievances (Railton 1986). It has to be conceded nevertheless that societies do not deliberately test moral claims in this fashion. To the third objection, it can be pointed out that if, objectively speaking, it is wrong to take stamps and money from the secretary's desk when he is out to lunch, there is no special moral argument that would lead one who denied this to conclude (in the typical case) that it was really permissible. And to the fourth objection, the reply is that the things that are true are the things we know. Combustion most certainly involved oxygen before we knew it, but it is meaningless to say that it was true before we knew it.

Finally, it will be argued that it might be the case that vegetarianism is morally obligatory though we never get to the point of acknowledging this as a moral truth. I simply deny the claim, unless it is interpreted as the claim that we will some day discover this to be true but the discovery will be somehow suppressed.

\section{$4 \mathrm{Iv}$}

The Darwinian dilemma would threaten all our knowledge if we were unable to take a critical perspective on our evolutionarily-implanted intuitions and if we had to accept a realist account of the existence of facts independent of knowledge-generating procedures.

The solution I have proposed requires us to identify, confidently, instances of undisputed moral progress and to understand each as having a distinctive narrative of discovery that may run parallel to other narratives. But this point does not address the question how the biological, ethnographic, and psychological discoveries of the last century may have a role to play in advancing moral knowledge. 'Is' can never lead to 'ought,' is a plaintive refrain not only of the philosophers but of the biologists themselves.

Strictly speaking this is false. No ought- statement logically follows from a set of isstatements, but we constantly make these inferences. For example:

When people become inebriated they are tired, emotional and poorly co-ordinated.

To fly a passenger plane safely without crashing, it is essential to be alert, calm, and coordinated

Pilots should not fly passenger planes when inebriated.

This is an important normative conclusion. As a general rule (subject to exceptions) it qualifies as objective. The argument leading to it is a good one, but only because first, the factual premises are true; second, there is a suppressed normative premise -that it is bad to 
crash planes - that is a safe assumption; and third, because no reason has been presented for why we ought to make an exception in some particular case, concluding that an inebriated pilot ought to be permitted or required to fly a plane. (If, for example, there is some chance of escaping a fate worse than death for the passengers.)

Accordingly, the way is open for making good arguments about what ought to happen based on true factual premises drawn from the human sciences, provided the additional normative premises they depend on are safe assumptions; and provided there are no reasons to make an exception. Such arguments are however always vulnerable. For first, some factual premises reflect how things are now, but not how they must be; second, our conception of what a safe normative assumption is can change; and third, new reasons for making exceptions can appear at any time. Consider for example the following argument which appeared flawless to past generations:

\section{Argument 1}

Mothers have a strong preference not to be separated from their infants for more than a few hours at a time.

The lucrative and visible professions require long hours spent in adult company Therefore, mothers of infants do not belong in the lucrative and visible positions.

Today we might argue:

\section{Argument 2}

Mothers have a strong preference not to be separated from their infants for more than a few hours at a time.

The lucrative and visible professions require long hours spent in adult company

Therefore, the workplaces and time allocations in the lucrative and visible professions ought to be restructured.

Argument 1, which depends on the generally agreed normative premise that women should not be made unhappy, is nevertheless vulnerable to the presentation of an 'except that' reason. In this case, it is that the exclusion of women from the visible and lucrative positions is antimeritocratic and does not permit the development and exercise of women's capabilities. Argument 2 depends on the same general premise that people should not be made unhappy, but it is vulnerable to a different presentation of an 'except that' reason. In this case, it is that it would be too troublesome and costly to restructure the working day and workplace facilities. As we are beginning to see an evolution away from Argument 1 towards acceptance of Argument 2 , we may have the intimation that the workplace will be restructured to a greater degree in the future and that this will constitute moral progress. The narrative of how this comes about will involve reference to court cases, editorials, personal narratives, and philosophy articles.

The new human sciences, including evolutionary psychology, endeavour to distinguish between preferences, tendencies, and capabilities that are less influenced by social learning and by contingent social arrangements and those that are more malleable, and between those that are malleable without inducing suffering and those that are not. They look for unconscious as well as conscious motives relevant to survival, reproduction, and the furtherance of the interests of kin and kith that can explain social behaviour. In any case in which they present us with a well-established conclusion, for example than people vary in traits relevant to their potential to earn large sums, or that men are more sexually aggressive and less selective than women, there will be two opposing arguments ready to be formulated. One will be an argument for indulging or tolerating a preference or tendency on the part of one party even 
if it is to the disadvantage of another party; the other will be an argument for repressive measures undertaken 'against nature,' seen as a repository of disorderly forces needing to be tamed (Mill 1904; Huxley 2004) in order to protect the interests of the other party affected by the preference or tendency.

Other things being equal, it is inefficient, ineffectual and frustrating to devise social policies that go against people's preferences, tendencies, and reactive attitudes. Our institutions should respect what we are biologically speaking, ingenious, outdoorsy, kin-focussed, sexually curious. As the foregoing makes clear, there can be no direct, uncontroversial 'arguments from nature,' that can establish certain practices and policies as morally better than others. Nevertheless, empirical research can undermine essentialisms, the typically binary classification systems humans use, and the stereotypes that enable them to make quick social judgements. We discover that the species is polymorphic in many dimensions; people differ significantly in terms of ambitiousness, promiscuity, altruism, empathy, sexual identity, and so on, and that although differences in emotions and competencies between men and women are real, their magnitude and significance is exaggerated in our socio-economic systems. Behaviour is flexible and opportunistic; 'mating strategies' in humans are not fixed routines but conditional on personalities and circumstances (Gangestad and Simpson 2000).

At the same time, small differences in preferences can unleash major moral and social problems. In the environment of early adaptation, for example, both sexes were vulnerable to frustration of their immediate interests on account of the preferences of the other. Men endured rejection and women were pestered. The power relations of the modern workplace have both upset the equilibrium, making it more difficult to escape pestering and exercise rejection and rendering any decision taken by the woman more likely to damage than to advance her career. To devise remedies, we need first to accept the fact that reproductive strategies are amenable to but also resistant to re-education, that male and female reproductive strategies, underwritten by cognitive and emotional mechanisms, conflict to some extent, and that individuals vary in their levels of educability. By seeing male sexual solicitation, for example, as normal and frequent rather than as unusual and perverse behaviour, recognising at the same time that it is seriously deleterious to the interests of young working women, we can clear away some of the clouds of confusion surrounding this issue.

Second, the human sciences can demystify certain forms of authority, hierarchy, and group behaviour. If we come to see participation in modern warfare as a human version of participation in chimpanzee raiding parties, and as underwritten by emotional structures that make it fulfilling for many who participate in it (Wrangham and Petersen 1996; Liddell Hart 1933), we will cease to regard it as a glorious means of determining whose cause is just and see it instead as the irrational atavism it really is. If we come to understand magic and religion, the belief in unseen personalities exercising powerful causal influences and to some degree able to be placated by human behaviour, as adaptations appearing in human cognitive architecture that made human social life and its modes of subsistence possible (Atran and Norenzayan 2004; Hocart 1970), we will not dismiss either as foolish nonsense, but rather try to convert the emotional power at least of the latter to constructive rather than destructive enterprises.

To summarise, the potential objectivity of moral beliefs can be understood within a naturalistic framework by considering moral truth as the outcome of diachronic processes of enquiry resulting in belief-change for the better. Taking up a scientific perspective on human cognition, emotion, and behaviour contributes to the process of belief-improvement by supplanting folk wisdom. There are, however, no set criteria by which two opposing moral beliefs can be directly compared to see which one is correct. As with the experimental 
sciences, we can recognise the superiority of the later view only by coming to appreciate the narratively unique critical process by which it emerged from the inferior alternative. To be rationally, as opposed to merely fideistically convinced that a moral belief is true though as yet unknown to be so is to believe that it could emerge from an inferior alternative by a unique critical process bearing some similarity to the critical processes that showed us that slavery, torture, the restriction of voting rights and occupations, cruelty to animals, and aristocratic privilege were objectively morally wrong.

Open Access This article is distributed under the terms of the Creative Commons Attribution 4.0 International License (http:/creativecommons.org/licenses/by/4.0/), which permits unrestricted use, distribution, and reproduction in any medium, provided you give appropriate credit to the original author(s) and the source, provide a link to the Creative Commons license, and indicate if changes were made.

\section{References}

Ananth M (2005) Psychological altruism vs. biological altruism: narrowing the gap with the Baldwin effect. Acta Biotheor 53(3):217

Atran S, Norenzayan A (2004) Religion's evolutionary landscape: Counterintuition, commitment, compassion, communion. Behav Brain Sci 27:1-57

Blackburn S (1984) Spreading the word. Oxford University Press, Oxford

Boehm C et al (1993) Egalitarian behavior and reverse dominance hierarchy (and comments and reply). Curr Anthr 34(3):227-254

Copp D (2007) Morality in a natural world: selected essays in metaethics. Cambridge University Press, Cambridge

de Waal F (1996) Good natured: the origins of right and wrong in humans and other animals. Harvard University Press, Cambridge

de Waal F (2006) Primates and philosophers. Princeton, Princeton University Press

Darwin C (1871/2004) The descent of man and selection in relation to sex, 2nd. ed. repr. London, Penguin

Dawkins R (1976) The selfish gene. Granada, London

Gangestad SW, Simpson JA (2000) The evolution of human mating: trade-offs and strategic pluralism. Behav Brain Sci 23(4):573-587

Gibbard A (1990) Wise choices, apt feelings: A theory of normative judgment, Cambridge, Harvard University Press, and Oxford, Oxford University Press

Harman G (1977) The nature of morality. Oxford University Press, Oxford

Hocart AM (1970) Kings and councillors: an essay in the comparative anatomy of human society. University of Chicago Press, Chicago and London

Huxley TH (2004) Evolution and ethics. Amherst, Prometheus

Jackson F, Pettit P (1996) Moral functionalism, supervenience and reductionism. Phil Quart 46(182):82-86

Joyce R (2002) The myth of morality. Cambridge University Press, Cambridge

Kitcher P (2006) Between fragile altruism and morality: Evolution and the emergence of normative guidance. In: Boniolo G, de Anna G (eds) Evolutionary ethics and contemporary biology. Cambridge University Press, Cambridge, pp 178-199

Liddell Hart BH (1933) Foreword to S. Rogerson, Twelve days, London, A. Baker

McDowell J (1988) Values and secondary qualities. In: Sayre-McCord G (ed) Essays on moral realism. Cornell University Press, Ithaca and London, pp 166-180

Mill JS (1904) Nature, the utility of religion and theism. Watts \& Co, London

Mizrahi M (2013) What is scientific progress? Lessons from scientific practice. J Gen Philos Sci 44(2):375-390

Price H (2011) Naturalism without mirrors. Oxford University Press, Oxford

Prinz J (2006) The emotional basis of moral judgements. Philosophical Explorations 9:29-43

Prinz J (2007) The emotional construction of morals. Clarendon, Oxford

Railton P (1986) Moral realism. Phil Rev 95:163-207

Robarchek CA, Robarchek CJ (1992) Cultures of war and peace: a comparative study of Waorani and Semai. In: Silverberg J, Gray JP (eds) Aggression and peacefulness in humans and other primates. Oxford University Press, New York and Oxford, pp 189-213 
Robarchek CA, Robarchek CJ (1992) “A comparative study of Waorani and Semai." Aggression and peace in humans and other primates, pp 188-213

Ruse M (2006) Is darwinian metaethics possible and if it is is it well taken? In: Boniolo G, de Anna G (eds) Evolutionary ethics and contemporary biology. Cambridge University Press, Cambridge, pp 13-16

Ruse M, Wilson EO (1985) The evolution of ethics. New Sci 1478:50-52

Street S (2006) A darwinian dilemma for realist theories of value. Phil Stud 127:109-166

Street S (2008) 'Constructivism about reasons. 'In: R. Shafer-Landau, ed. Oxford studies in metaethics, vol. 3, Oxford, Clarendon, pp 207-46

Smith M (2004) "Does the Evaluative Supervene on the Natural?". In: Smith J (ed) Ethics and the A Priori. Cambridge, Cambridge University Press, pp 208-233.

Tooby J, Cosmides L (1996) Friendship and the banker's paradox: other pathways to the evolution of adaptations for altruism. Proc Brit Acad 88:119-144

Trivers RL (1971) The evolution of reciprocal altruism. Quart Rev Bio 46(1):35-57

Williams B (1981) Internal and external reasons. In: Moral luck. Cambridge University Press, Cambridge, pp $101-113$

Wilson C (2010) Moral progress without moral realism. Phil Pap 39(1):97-116

Wilson C (2011) Moral truth-observational or theoretical? Proc Arist Soc 111:95-112

Wrangham R, Petersen D (1996) Demonic males: apes and the origin of human violence. Houghton Mifflin, New York 